\title{
HUBUNGAN BERAT BADAN LAHIR RENDAH (BBLR) DENGAN KEJADIAN STUNTING PADA ANAK USIA 1-3 TAHUN
}

\author{
Beauty Grace Nainggolan', Monalisa Sitompul ${ }^{2}$ \\ ${ }^{1,2}$ Fakultas Ilmu Keperawatan, Universitas Advent Indonesia
}

Emai : nainggolan.grace@ymail.com

\begin{abstract}
Nutrition is an important part of growth and development, because there is a link between health and intelligence. Nutritional problems, especially stunting in children is one of the malnutrition conditions which is a major concern in the world, especially in developing countries. Stunting is a problem of chronic malnutrition caused by insufficient nutritional intake in a long time due to feeding that does not fit nutritional needs and is a major threat to human quality, and the competitiveness of the Indonesian people. The purpose of this study was to determine the relationship between $L B W$ and the incidence of stunting in children aged 1-3 years. This study uses the descriptive method. Data collection uses open interview techniques. The number of samples in this study were 38 respondents using total sampling and the test used was Chi Square. The results showed that the value of $P$ value is 0.005 so it can be concluded that there is a significant relationship between $L B W$ and the incidence of stunting. This research can be an input for the quality of health services and scientific development, skills in the field of child nursing so that active role of health promotion is expected in the nutrition of pregnant women as prenatal and neonatal preparations in order to reduce the incidence of low birth weight impacting stunting. Other researchers are expected to develop this research with other variables as a factor characteristics parents, genetic, infectious diseases, and feeding that do not fit.
\end{abstract}

Keywords : LBW, Stunting in children aged 1-3 years

\begin{abstract}
Abstrak
Gizi merupakan bagian penting dalam pertumbuhan dan perkembangan, karena terdapat keterkaitan antara kesehatan dan kecerdasan. Permasalahan gizi, khususnya stunting pada anak merupakan salah satu keadaan kekurangan gizi yang menjadi perhatian utama di dunia terutama di negara-negara berkembang. Stunting merupakan masalah kurang gizi kronis yang disebabkan oleh asupan gizi yang kurang dalam waktu cukup lama akibat pemberian makanan yang tidak sesuai kebutuhan gizi dan merupakan ancaman utama terhadap kualitas manusia, dan daya saing bangsa Indonesia. Tujuan penelitian ini adalah untuk mengetahui hubungan antara BBLR dengan kejadian stunting pada anak usia 1-3 tahun. Penelitian ini menggunakan metode descriptive. Pengumpulan data menggunakan teknik wawancara terbuka. Jumlah sampel pada penelitian ini sebanyak 38 responden dengan menggunakan total sampling dan uji yang digunakan adalah Chi Square. Hasil penelitian didapatkan bahwa nilai Pvalue 0,005 sehingga dapat disimpulkan ada hubungan signifikan antara BBLR dengan kejadian stunting. Penelitian ini dapat menjadi bahan masukan untuk mutu pelayanan kesehatan dan pengembangan keilmuan, keterampilan dalam bidang keperawatan anak sehingga diharapkan adanya peran aktif promosi kesehatan tentang gizi ibu hamil sebagai persiapan prenatal maupun neonatal agar dapat menurunkan angka kejadian BBLR yang berdampak stunting. Kepada peneliti lain diharapkan dapat mengembangkan penelitian ini dengan variabel yang lain seperti faktor genetik, penyakit infeksi, maupun pemberian makan yang tidak sesuai .
\end{abstract}

Kata Kunci : BBLR, Stunting pada anak 


\section{Pendahuluan}

Gizi adalah bagian penting dalam pertumbuhan dan perkembangan anak yang merupakan salah satu faktor yang mempengaruhi kesehatan dan kecerdasan pada anak (Ririn, 2016). Permasalahan gizi, khususnya stunting pada anak merupakan salah satu keadaan kekurangan gizi yang menjadi perhatian utama di dunia terutama di negara-negara berkembang (Darwin 2014).

Stunting merupakan masalah kurang gizi kronis yang disebabkan oleh asupan gizi yang kurang dalam waktu cukup lama akibat pemberian makanan yang tidak sesuai kebutuhan gizi (MCA-Indonesia, 2014). Kekurangan gizi terjadi sejak bayi masih dalam kandungan dan pada masa awal setelah bayi lahir, akan tetapi kondisi stunting baru nampak setelah bayi berusia 2 tahun.

Prevalensi stunting di dunia sebesar 26,9\% dan di negara-negara berkembang di Asia sebesar 31,3\%. Berdasarkan hasil PSG (2015), prevalensi balita pendek di Indonesia mencapai angka $29 \%$. Angka ini mengalami penurunan pada tahun 2016 menjadi 27,5\%. Namun prevalensi balita pendek pada tahun 2017 kembali meningkat menjadi 29,6\% (Buletin Stunting, 2018).Sementara itu, Badan Kependudukan dan Keluarga Berencana Nasional (BKKBN) Jawa Barat melansir prevalensi stunting di Jawa Barat sudah mencapai angka 29,2\% atau 2,7 juta balita termasuk di delapan kabupaten/kota yang memiliki prevalensi stunting masih tinggi (BKKBN, 2018).Delapan kabupaten/kota yang memiliki prevalensi stunting masih tinggi diantaranya: Garut (43,2\%), Sukabumi $(37,6 \%)$, Tasikmalaya $(33,3 \%)$, Bandung Barat $(34,2 \%)$, Majalengka $(30,2 \%)$ dan Purwakarta $(30,1 \%)$ (BAPPEDA, 2018).

Stunting merupakan ancaman utama terhadap kualitas manusia Indonesia, juga ancaman terhadap kemampuan daya saing bangsa. Hal ini dikarenakan stunted, bukan hanya terganggu pertumbuhan fisiknya (bertubuh pendek/kerdil) saja, melainkan juga terganggu perkembangan otaknya, yang mana tentu akan sangat mempengaruh kemampuan dan prestasi di sekolah, juga produktivitas dan kreativitas di usia-usia produktif (DepKes, 2018).
Beberapa faktor yang mempengaruhi kejadian stunting antara lain faktor karakteristik orang tua seperti pendidikan, pekerjaan, pendapatan, pola asuh, pola makan, faktor genetik, penyakit infeksi, kejadian berat badan lahir rendah, kekurangan energi dan protein, sering mengalami penyakit kronis, dan praktik pemberian makan yang tidak sesuai.

Defisiensi energi kronis atau anemia selama kehamilan dapat menyebabkan ibu melahirkan bayi dengan berat badan lahir rendah. Stunting yang dialami anak dapat pula disebabkan oleh tidak terpaparnya periode 1000 hari pertama kehidupan (golden periode) mendapat perhatian khusus karena menjadi penentu tingkat pertumbuhan fisik, kecerdasan, dan produktivitas seseorang di masa depan. Selain itu pada masa tersebut nutrisi yang diterima bayi didalam kandungan dan menerima ASI memiliki dampak jangka panjang terhadap kehidupan saat dewasa. Jika hal ini dapat dilalui dengan baik maka akan terhindar dari terjadinya stunting pada anak (DepKes, 2015).

Menurut Hidayat (2008), penilaian pertumbuhan fisik pada anak dapat dilakukan dengan pengukuran antropometri, pemeriksaan fisik, pemeriksaan laboratorium, dan pemeriksaan radiologi. Pemeriksaan antropometri ini meliputi pengukuran berat badan, tinggi badan, lingkar kepala, dan lingkar lengan atas.

Tingginya angka BBLR diperkirakan menjadi penyebab tingginya kejadian stunting di Indonesia. Penelitian di Malawi dengan desain kohort menunjukkan bahwa berat badan lahir rendah merupakan prediktor terkuat kejadian stunting pada balita usia 12 bulan (Friska, 2014). Pada penelitian lainnya oleh Sulastri (2012), mendapatkan bahwa penyebab stunting pada anak sekolah adalah tingkat pendidikan ibu dan tingkat ekonomi. Penelitian Hidayah (2013) menemukan bahwa ada hubungan bermakna antara ASI eksklusif dengan kejadian stunting pada anak.

Berdasarkan uraian diatas, peneliti tertarik untuk lebih lanjut mengenai Hubungan Berat Badan Bayi Lahir Rendah (BBLR) dengan kejadian Stunting pada anak usia 1-3 tahun di salah satu wilayah kerja Puskesmas Bandung Barat tahun 2019. 


\section{Metode Penelitian}

Penelitian ini menggunakan metode deskriptif korelasional melalui pendekatan cross sectional. Sehingga pada pengumpulan data penelitian ini peneliti menggunakan kuesioner. Pada penelitian ini menggunakan 2 analisa yaitu analisa univariat untuk menghitung distribusi frekuensi dan analisa bivariat menggunakan uji chi square karena data yang digunakan adalah kategorik.

\section{Skema 1 Kerangka}

Konsep Penelitian

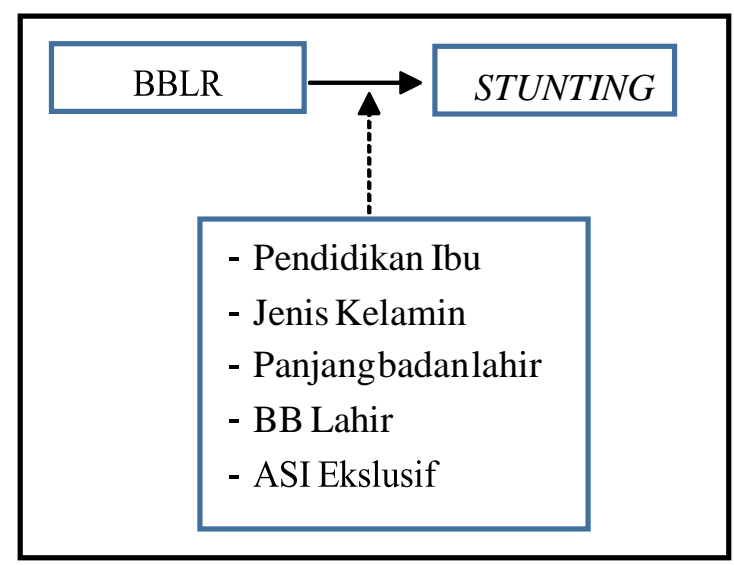

Keterangan

BBLR : Variabel Independen

Stunting : Variabel Dependen

Covariate - - - - -

Penelitian ini dilakukan pada bulan Mei di salah satu wilayah kerja Puskesmas Bandung Barat tahun 2019. Dalam penelitian ini penulis menggunakan teknik pengambilan sampel dengan menggunakan total sampling. Total sampling adalah pengambilan sampel yang sama dengan jumlah populasi yang ada (Arikunto, 2006). Instrumen yang digunakan untuk pengumpulan data adalah kuesioner yang terdiri dari nama anak, pekerjaan ibu, pendidikan ibu, BB lahir anak, panjang badan lahir anak, riwayat ASI eksklusif, riwayat imunisasi lengkap. Sehingga jumlah sample pada penelitian ini sebanyak 38 responden.

\section{Hasil Penelitian}

Hubungan berat badan bayi lahir rendah dengan kejadian stunting pada anak di salah satu wilayah kerja Puskesmas Bandung Barat bulan Mei tahun 2019.

Tabel 1. Distribusi Frekuensi Variabel Covariate

\begin{tabular}{lcl}
\hline Kategori & Frekuensi & \% \\
\hline Pendidikan Ibu & & \\
SD & 16 & 42,1 \\
SMP & 8 & 21,1 \\
SMA & 14 & 36,8 \\
PT & - & - \\
Total & 38 & 100 \\
\hline Jenis Kelamin & & \\
Anak & & \\
Perempuan & 20 & 52,6 \\
Laki-laki & 18 & 47,4 \\
Total & 38 & 100 \\
\hline ASI Ekslusif & & \\
Ya & 22 & 57,9 \\
Tidak & 16 & 42,1 \\
Total & 38 & 100 \\
\hline PBL Anak & & \\
$<45 \mathrm{~cm}$ & 2 & 5,3 \\
$\geq 45 \mathrm{~cm}$ & 36 & 94,7 \\
Total & 38 & 100 \\
\hline BBL Anak & & \\
$<2500$ gram & 29 & 76,3 \\
$\geq 2500$ gram & 9 & 23,7 \\
Total & 38 & 100 \\
\hline
\end{tabular}

Berdasarkan tabel 1 distribusi responden berdasarkan pendidikan ibu bahwa sebagian besar ibu responden berpendidikan SD yaitu 16 responden (42,1\%). Distribusi responden berdasarkan jenis kelamin menunjukan bahwa 20 responden $(52,6 \%)$ berjenis kelamin perempuan. Distribusi responden berdasarkan pemberian ASI Eksklusif menunjukan bahwa sebanyak $22(57,9 \%)$ memiliki riwayat ASI Eksklusif. Responden berdasarkan PBL Anak bahwa sebesar $94,7 \%$ anak memiliki panjang badan lahir $\geq 45 \mathrm{~cm}$ sebanyak 36 responden (100\%). Responden berdasarkan BBL Anak bahwa sebagian besar responden memiliki BBL <2500gram yaitu 9 responden $(76,3 \%)$. 
Tabel 2. Hubungan Berat Badan Bayi Lahir Rendah (BBLR) dengan kejadian Stunting

\begin{tabular}{|c|c|c|c|c|c|c|c|c|}
\hline \multirow{3}{*}{$\begin{array}{c}\text { Jenis } \\
\text { Faktor }\end{array}$} & \multicolumn{4}{|c|}{ BBL } & \multirow{2}{*}{\multicolumn{2}{|c|}{ Total }} & \multirow{3}{*}{ PR } & \multirow{3}{*}{$\begin{array}{c}P \\
\text { Value }\end{array}$} \\
\hline & \multicolumn{2}{|c|}{ Normal } & \multicolumn{2}{|c|}{ Rendah } & & & & \\
\hline & $\mathrm{n}$ & $\%$ & $\mathrm{n}$ & $\%$ & $\mathrm{n}$ & $\%$ & & \\
\hline Ya & 9 & 23,7 & 4 & 10,6 & 13 & 34,3 & & \\
\hline Tidak & 0 & 0 & 25 & 65,7 & 25 & 65,7 & 25,5 & 0,005 \\
\hline Total & 9 & 23,7 & 29 & 76,3 & 38 & 100 & & \\
\hline
\end{tabular}

Pada tabel 2 Hubungan Berat Badan Bayi Lahir Rendah (BBLR) dengan kejadian Stunting pada anak di salah satu wilayah kerja Puskesmas Bandung Barat. Hasil uji statistik didapatkan nilai Pvalue 0,005 yang artinya Pvalue $>0,05$, maka dapat disimpulkan ada hubungan yang signifikan antara Berat Badan Bayi Lahir Rendah (BBLR) dengan kejadian Stunting. Dengan nilai PR 25,5, artinya bayi yang mengalami BBLR mempunyai peluang 25 kali untuk mengalami stunting dibandingkan bayi yang BBL normal.

Pembahasan

Hasil data yang didapat, berdasarkan tingkat pendidikan ibu responden menunjukan 16 responden $(42,1 \%)$ dengan pendidikan SD. Pendidikan merupakan pembelajaran pengetahuan, keterampilan, dan kebiasaan seseorang, semakin tinggi tingkat pendidikan seseorang maka semakin banyak pengetahuan yang didapat dan semakin mudah dalam memperoeh pekerjaan (Desiana, 2018). Sebaliknya pendidikan yang kurang akan menghambat perkembangan sikap seseorang terhadap nilai-nilai yang baru dikenal. Selain itu, tingkat pendidikan turut menentukan mudah tidaknya seseorang menyerap dan memahami pengetahuan gizi dan kesehatan. Hal ini berkaitan erat dengan wawasan pengetahuan mengenai sumber gizi dan jenis makanan yang baik untuk konsumsi keluarga. Kondisi demikian ini menyebabkan orang tua kurang optimal dalam memenuhi kebutuhan gizi anak, sehingga menyebabkan anak mengalami stunting (Almatsir dalam Putra, 2016).

Berdasarkan hasil data jenis kelamin yang didapat, bahwa sebanyak 20 responden
$(52,6 \%)$ berjenis kelamin perempuan. Hal tersebut sejalan dengan penelitian yang dilakukan oleh Winowatan (2016) bahwa kejadian stunting pada anak perempuan lebih banyak dibanding anak laki-laki. Namun hal ini tidak sesuai dengan penelitian yang dilakukan oleh Nadiyah (2014) dimana anak yang berjenis laki- laki cenderung lebih besar terjadi stunting dibanding anak perempuan.

Berdasarkan hasil data riwayat ASI Ekslusif didapat, jumlah responden yang mendapatkan ASI Ekslusif sebanyak 22 responden (57,9\%). Hal tersebut sama dengan penelitian yang dilakukan oleh Putra pada tahun (2016), hasil menunjukan bahwa pemberian ASI Ekslusf tidak berhubungan secara signifikan terhadap kejadian stunting. Akan tetapi, jika tidak memberikan ASI Ekslusif akan meningkatkan risiko sebesar 2 kali terhadap kejadian stunting. Hasil ini tidak sejalan dengan penelitian yang dilakukan oleh Hidayah (2013) yang mengemukakan bahwa ada hubungan bermakna antara ASI eksklusif dengan kejadian stunting pada anak.

ASI adalah cairan hidup yang mengandung zat kekbalan tubuh yang akan melindungi bayi dari berbagai penyakit infeksi bakteri, virus, parasit dan jamur. ASI mengandung lebih dari 200 unsur-unsur pokok, antara lain zat putih telur, lemak, karbohidrat, vitamin, mineral, faktor pertumbuhan, hormon, enzim, zat kekebalan, dan sel darah putih. Semua zat ini terdapat secara proporsional dan seimbang satu dengan yang lainnya (Fikawati, 2015). Rekomendasi dari The American Dietetic Association (ADA) dan The American Academy of Pediatric (AAP) adalah memberikan ASI Eksklusif. Pemberian ASI Eksklusif dilakukan pada bayi selama 6 bulan pertama, kemudian dilanjutkan dengan diberikan makanan pendamping ASI (MP-ASI) minimal hingga usia 24 bulan (Trahms, 2004).

Hasil hubungan Berat Badan Bayi Lahir Rendah (BBLR) dengan kejadian Stunting pada anak di Wilayah Kerja Puskesmas Bandung Barat, berdasarkan uji statistik Chi square diperoleh nilai Pvalue 0,005 artinya Pvalue > 0,05, sehingga disimpulkan ada hubungan yang signifikan antara hubungan Berat Badan Bayi Lahir Rendah (BBLR) dengan kejadian Stunting pada anak. Berat 
badan lahir rendah (BBLR) adalah bayi yang lahir dengan berat badan lebih rendah dari berat badan bayi rata-rata $(<2500$ gram $)$. Akibat berat badan yang kurang maka akan terjadi kekurangan zat gizi juga, maka simpanan zat gizi pada tubuh digunakan untuk memenuhi kebutuhan. Apabila keadaan ini berlangsung lama, maka simpanan zat gizi akan habis dan akhirnya terjadi kemerosotan jaringan, rendahnya tingkat hemoglobin, serum vitamin A dan karoten, peningkatan asam laktat dan piruvat. Pada saat ini orang sudah dapat dikatakan stunting.

Hasil tersebut sama dengan penelitian yang dilakukan oleh Rahayu (2015) dan Putra pada tahun (2016), hasil penelitian menunjukan ada hubungan antara BBLR dengan kejadian stunting pada anak dibawah usia 2 tahun. Namun penelitian ini tidak sejalan dengan penelitian yang dilakukan oleh Winowatan pada tahun (2016), hasil penelitian menunjukan bahwa tidak terdapat hubungan antara berat badan lahir dengan stunting pada balita. Hal tersebut dikarenakan berat badan yang merupakan salah satu ukuran tubuh yang paling banyak digunakan dalam memberi gambaran massa jaringan, termasuk jaringan tubuh sangat mudah dipengaruhi oleh keadaan mendadak, seperti terserang infeksi atau diare, konsumsi makanan yang menurun (Gizi Indonesia).

Selain itu juga beberapa faktor yang mempengaruhi kejadian stunting seperti status ekonomi yang menjadi penunjang dalam tumbuh kembang anak, karena orang tua dapat menyediakan semua kebutuhan anak baik primer maupun sekunder (Soetjiningsih, 2004). Anak kurang gizi yang daya tahan terhadap penyakitnya rendah, jatuh sakit, sehingga mengurangi kapasitasnya untuk melawan penyakit (Sitepoe, 2013). Sehingga hal ini dapat menggambarkan adanya gangguan pertumbuhan tinggi badan dan menurunnya berat badan (Welassih, 2012)

\section{Kesimpulan}

Hasil uji statistik Chi square diperoleh nilai Pvalue 0,005 artinya Pvalue $>0,05$, sehingga disimpulkan ada hubungan yang signifikan antara hubungan Berat Badan Bayi Lahir Rendah (BBLR) dengan kejadian Stunting pada anak. Nilai Prevalance Ratio (PR) yang diperoleh sebesar 25,5 artinya, bayi yang mengalami BBLR mempunyai risiko 25 kali untuk mengalami stunting dibandingkan bayi yang BBL normal.

\section{Saran}

Hasil penelitian ini diharapkan dapat menjadi bahan masukan untuk mutu pelayanan kesehatan dan pengembangan keilmuan, keterampilan dalam bidang keperawatan anak sehingga diharapkan adanya peran aktif promosi kesehatan tentang gizi ibu hamil sebagai persiapan prenatal maupun neonatal agar dapat menurunkan angka kejadian BBLR yang berdampak stunting. Kepada peneliti lain diharapkan dapat mengembangkan penelitian ini dengan variabel lain yang lebih luas dan uji statistik yang memiliki akurasi lebih.

\section{Daftar Pustaka}

Almatsier. (2003). Prinsip Dasar Ilmu

Gizi. Jakarta : PT Gramedia

Pustaka Utama ; 132

Balitbangkes. (2018). Riset Kesehatan

Dasar. Jakarta : Kementerian

Kesehatan RI

DKK. (2018). Profil Kesehatan Prov. Jawa Barat.

Fikawati. (2015). Gizi Ibu dan Bayi. Jakarta : PT Grafindo Persada

Friska. (2014). Pengaruh BBL terhadap Kejadian Stunting. Malawi : UMS

Hidayah, F. (2013). Eksklusif sebagai

Faktor Kejadian Stunting pada

Anak. Yogyakarta : UGM ; 24-25

Notoatmodjo. (2010). Metodologi

Penelitian Kesehatan. Jakarta :

Rineka Cipta

Nursalam. (2014). Metodologi Penelitian

Ilmu Keperawatan Edisi 3. Jakarta : 
Salemba Medika

Putra, Onetusfifsi. (2016). Pengaruh BBLR terhadap kejadian stunting pada anak. Padang : Universitas Andalas ; 11-12

Rahayu, Atikah. (2016). Riwayat BBL dengan Kejadian Stunting pada Anak Usia dibawah Dua Tahun. Banjarmasin : Universitas Lambung Mangkurat ; 67-68

Ririn. (2016). Pengaruh Pos Gizi terhadap Pengetahuan dan Pola Asuh Ibu Balita. Ngawi : UMS

SitepoeM. (2013). ASI Eksklusif. Jakarta : PT. Index

Soetjiningsih. (2004). Tumbuh Kembang Anak. Jakarta : EGC

Trahms, dkk. (2004). Krauses food, nutrition, and diet therapy. USA : Saunders

Welassih BD. (2012). Beberapa Faktor yang berhubungan dengan Status Gizi Balita Stunting. The Indonesian Journal of Public Health ; 8

Winowatan, Gabrielisa. (2015). Hubungan antara BBL anak dengan Balita. Indonesia : Fakultas Kesehatan Masyarakat Universitas Sam Ratulangi ; 4 